\title{
Environmental Contribution Of Community Forests For Food Production With Agroforestry Patterns
}

\author{
Anang Susanto ${ }^{1 *}$, Marti Winarni ${ }^{2}$, Maher Nasser Abdullah ${ }^{3}$, Dana Briggs ${ }^{4}$ \\ ${ }^{1,2}$ Departemen of Agricultural Science, of Merdeka University, Jl. Serayu79 \\ Madiun, East of Java,Indonesia \\ ${ }^{3}$ Al-Muthanna University, Iraq \\ ${ }^{4}$ California State University, Monterey Baydisabled, Marina, United States \\ * Corresponding author: Anang Susanto \\ Email: Asmadiun@yahoo.com
}

\begin{abstract}
.
Application of agroforestry systems in Indonesia through production forest programs in Java. Impact on the use of the production forest land. This research aims to present a variety of positive and negative effects on the use of production forest land for agricultural production in agroforestry systems. Agroforestry activities certainly have both positive and negative impacts on the primary production of forestry, the environment, and the income of communities living around the forest. Positive effects include: Increasing land productivity/value-added, accelerating the growth of primary production, providing short and medium-term income, reducing the risk of forest fires, Opening up forest fires.Employment opportunities, Improving the environment and biodiversity, reducing global warming, producing dry leaf mulch, and increasing people's income. The negative impact of agroforestry patterns is the tendency of agroforestry farmers to extend the farming time by disrupting primary production
\end{abstract}

Keywords: forest, production, community, income, impact

\section{INTRODUCTION}

Production forests continue to receive attention, especially from the government and the community. Develop production forest in the form of commercial production forest .[ 1] Use of productive forest land for agricultural production, such as, rainfed rice and maize, according to the agroforestry model, have long been applied in Java, including teak production forest (Tectona grandis), mahogany (Swietenia macrophylla). pine (Pinus markusii) and recently in albizia production forest (Falcataria moluccana) .[2] In the mountainous area, large areas of productive forest are used for vegetable production.[3] proposed a simple agroforestry system in Indonesia, called intercropping and the Indonesian version of the system wait. This system was developed in the Social Forestry program Perum Perhutani in Java. Utilization production forest area has certainly caused positive and negative impact on forest production, environment, and income people around the forest.

[4] This reseach aims to present positive and negative effects of using production forest land for agricultural production in agroforestry systems. Agroforestry 
is a blend of forestry and agriculture. The experts [5] defines agroforestry or agroforestry is a management system agricultural land continue to increase land productivity, combine forest production with agricultural production and or livestock simultaneously or successively on the same unit. weak environment and relatively vulnerable. In addition, the agroforestry model adopted by public.widely used according to .[ 6] as follows:

1) Agrisilviculture: combined production forestry with agricultural production for example, upland rice, corn, peanuts land etc.

2) Silvopastural: productio combination forestry with animal feed, for example, elephant grass, grass for animal feed other.

3) Silvofishery: production combination forestry (mangrove forest, swamp forest) with fisheries (milkfish, shrimp).

4) Agrosilvopasture production combination forestry,agricultural production, and feed cattle.

5) Agrosilvofishery: production combination forestry, agricultural production (long beans) and fisheries (fish) Types of agricultural production, animal feed, the types of fish found in the agroforestry pattern

\section{METHODS}

Study area

The research was conducted in the community forest of Ngawi district; data collection was carried out in the month of October-November 2020.

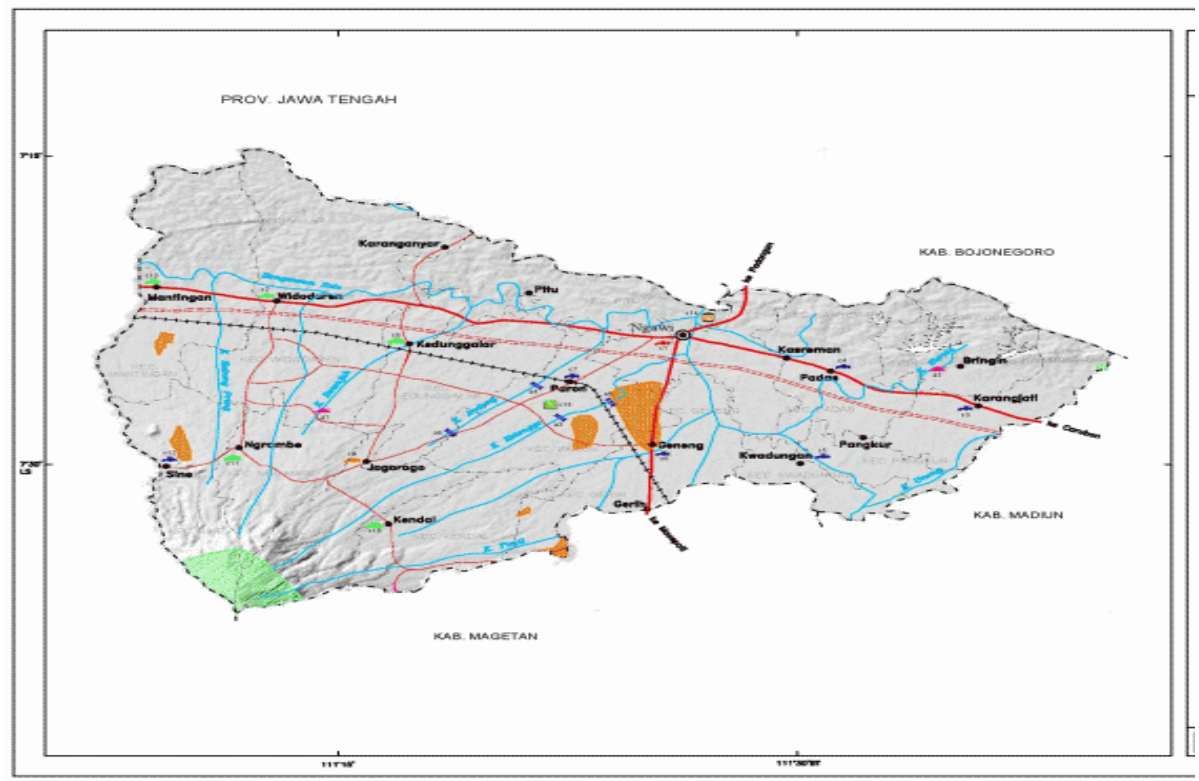

Fig 1. Study Area - Environmental contribution community forests, Ngawi Distric 
The sampling method used in community forests is stratified random sampling (Strata Sample), a random sampling of areas within a stratified population. The community forest area is then grouped into 3 categories, namely: narrow (area $<0.1 \mathrm{ha}$ ); medium (area between $0.1-0.2 \mathrm{ha}$ ) and wide (area $>2 \mathrm{ha}$ ). For each category, three replicates of community forest samples were taken so that the total number of samples was nine plots. Data collection in the sample plot was carried out with a Sampling Intensity (IS) of $100 \%$. Analysis of the structure of the yard is divided into the horizontal structure and vertical structure. In the horizontal structure, the parameter used is the base area (LBDS) area, while for the vertical structure.

\section{RESULT AND DISCUSSION}

Impact of forest land use production various impacts caused by cultivation of the agricultural output, horticulture, livestock, fisheries on forest land the show includes primary production, namely: forestry production (teak, mahogany, albizia, etc.) quite a lot as presented in table 1

Table 1. Types of agricultural crops, horticulture and fisheries in agroforestry patterns

\begin{tabular}{|l|l|l|l|l|}
\hline Grains & Roots & Vegetables & Fruits & Miscellaneous \\
\hline Upland & Garutt & beans & Pineapple & Tobacco \\
Rice & Ganyong & long beans & Papaya & Elephant grass \\
Peanuts & Porang & chili & banana & Nilam \\
Soybean & sweet potato & tomatoes & Jengkol & Pepper \\
mung & potato & Spinach & & meeting \\
beans & porang & Red onion & & yellow \\
& & Garlic & & Temu ireng \\
& & Kencur & & \\
& Ginger elephant & & Fishery \\
& & Ginger & & Fish mujaer \\
& & & & \\
& & & & \\
& & & & \\
& & & & \\
\hline
\end{tabular}

Source: Data in the studi, 2020

\subsection{Increase land productivity/value-added}

Good production forest land, dry land as well as swamp forests and mangroves which agricultural production (rice, corn,vegetables), fruit production, production fodder and fish will provide value added so that land productivity can be improved. The forest that was initially just produce forest, can produce other products when done with patterns agroforestry. [ 7] reported that agroforestry practices in development community forest has been flourishing. Combination of trees woods such as sengon, mangium, many and annual production, fodder grass has been applied by the community. Seasonal production commonly used are upland rice, corn, cassava, arrowroot, canna, taro, tubers tubers, iles-iles, suweg, kimpul, peanuts soil and soybeans 


\subsection{Accelerate the growth of staple production}

Agricultural production is grown on land production forest is generally given fertilizer so that agricultural production can be give high yields. Fertilizer that given to agricultural production later also used by the primary production, namely forestry production. Planting experiment resultslive (Ficus variegata Bl) in KHDTK Cikampek combined with production of cucumbers and subsequently beans length where fertilization is carried out with Sufficient urea, TSP and manure, has increased the growth of life. At the age of two years of life production has an average diameter of $7.22 \mathrm{~cm}$ and the average height is $6.90 \mathrm{~m}$ [ 8]. Planting Acacia mangium combined with upland rice on the pattern Insus with fertilizer application, let go increase the growth of this type of production.

\subsection{Provide short and medium-term income}

Agroforestry patterns have been able to provide faster yields before the final harvest. It depends on the type of production and age harvesting, long-term results will be obtained short such as monthly income, for example vegetables, quarterly payment for example fish, annual income such as fruit fruit [9]. This income is very useful for farmers for everyday life. In Wonosobo with albizia plants combined with bark has increased income significant farmers. Albizia production used as savings that will only be cut down when a hefty fee is needed, so that albizia production diameter can reach $40-50 \mathrm{~cm}$ where the price is relatively high. In Garut, the agroforestry pattern uses production of hemp or ramin as an ingredient textile raw materials. Furthermore, the design of farming under the stand African mahogany production forest (Khaya anthotheca) was carried out in Majenang, Java Central [10].

\subsection{Reducing the risk of forest fires}

Cultivated production forest lands with agricultural production, horticulture, feed livestock, and fisheries will always be guarded by farmers to obtain satisfying results. Production maintenance is carried out regularly. Thus the production will avoid the risk of fire. [11] Production trees in the middle of the agricultural output will also prevent the danger of fire, especially in the dry season. As It is known that forest fires occur a lot, especially in the dry season, because preventive measures must be taken. Loss due to large forest fires

\subsection{Open jobs}

Villages close to the forest production that applies agroforestry patterns, will get job opportunities starting from planting agricultural production, animal feed, fishery; maintenance activities include weeding, fertilization, and activities harvesting both farm production and primary production[12] .

\subsection{Improve the environment and Biodiversity}

Combined production forest land with agroforestry patterns will improve the background, for example, the use of terrace techniques seat. The number of types of 
production plant in production forest land will cause better biodiversity than with the land without agroforestry patterns

\subsection{Reduce global warming}

One of the causes of global warming is high $\mathrm{CO}^{2}$ on earth. On the other hand, plants able to absorb $\mathrm{C}^{2}$ in the processphotosynthesis. The more plants that planted in production forest land, the more there is also a lot of carbon sequestration, which in in turn, will reduce global warming [13].The Ministry of Forestry has implemented One Billion Trees Planting Program (OBIT) in 2018 with the aim of reduce global warming

\subsection{Produce dry leaf mulch}

Agroforestry activities on production forest land will produce dry leaf mulch leaves mulches). Dried leaf mulch (MDK) can be used for maintenance on staple production (sengon, mahogany, pine, etc.) [14] . The benefits of MDK are suppressing weeds, fertilize the soil when MDK ecomposes, stimulates root growth on the surface and in the destroyed MDK. Craftsman MDK use has been carried out in the production live in KHDTK Cikampek, West Java.

\subsection{Disrupt essential production.}

The negative impacts of agroforestry patterns are the tendency of agroforestry farmers to extend farming time through interfere with primary production. In the Perum area Perhutani, if introduction is less than $50 \%$, then production is deemed to have failed and is repeated on next year. In farmer's Silvofisheri pattern often interfere with mangrove production because The type of fish that is kept is milkfish requires full light. To overcome it needs to be socialized to the farmers. For example, raising fish milkfish is not allowed in the system pond forest, but can use fish Mujer that needs tree shade mangrove.

\subsection{Advantages and disadvantages of utilization production forest land}

Utilization of production forest land as a planting sites for agricultural production, horticulture, animal feed, and fisheries generally have more impact positive as previously described.However, it was also found that the impact negative, namely the tendency to prolong the time of agroforestry or silvofishery activities Agroforestry or agroforestry patterns should be applied to the production of forest land. Area community production forest land and forest people are suitable to be used for patterns agroforestry.

With a relatively large area trim, then HTR and HR match the pattern agroforestry. Industrial production forest land (HI) especially those located close to the village, may it be considered for application of agroforestry patterns. To improve welfare people, especially those who live near with production forest areas, the pattern agroforestry includes agrisilvicultural, silvopastural, silvofishery and agrosilvopasture can recommended to be applied in the field HTI, HTR, and HR production forests. 


\section{CONCLUSION}

Utilization of production forest land for agricultural production planting activities, fisheries, animal feed on the pattern agroforestry has been carried out by forest communities.production mostly positive good to the primary output of forestry, farmers forest owners, rural economy andenvironment. These impacts are (a) increase the added value/ productivity of production forest land (b) accelerate the growth of forest production (c) provide long-term income short and medium (d) reduce risk of forest fires (e) opening-up employment (f) improve environment and biodiversity (g) reduce global warming through $\mathrm{C} 02$ adsorption and (h) tendency interfere with primary production.

\section{REFERENCES}

[1] Bazame R., Tanrivermis H., Kapusuz Y. E. (2018). Land management and sustainable use of land resources in the case of Burkina Faso. Land degradation and development, 30 (6) : 608-621. .

[2] Dewi N, Wijayanto N, Gusmaini. 2017. Dimension growth of Azadirachta excelsa and Phyllabthus spp. in agroforestry system. Biodiversitas 18(2): 494-499.

[3] De Foresta, H., A. Kusworo, G. Michon dan W.W\A. Djatmiko. 2000. Ketika kebun berupa hutan. Agroforest Khas Indonesia. Sebuah Sumbangan Masyarakat. International Center for Research in Agroforestry. Bogor. Indonesia

[4] Neither W, Jacobi J, Blaser WJ, Andres C, Armengot A. 2020. Cocoa agroforestry systems versus monoculture: a multi-dimensional meta-analysis. Environ. Res. Lett. 15. DOI: $10.1088 / 1748-9326 / \mathrm{abb} 053$

[5] Sukandi, T., Sumarhani, Murniati. (2002). Informasi teknis. Pola wanatani (agroforestry). Pusat Litbang Hutan dan Konservasi Alam Bogor.

[6] Gladwin C.H., Peterson J.S., Phiri D., Uttaro R. (2002). Agroforestry adoption decisions, Structural adjustment and gender in Africa. In C. B. Barrett, F. Place \& A. A. Aboud (Eds.), Natural Resources Management in African Agriculture: Understanding and improving current practices (pp. 115-128).

[7] Widiarti, A. (2005). Gerhan : Hutan rakyat lebih menjanjikan penyediaan kayu, pangan Dan pelestarian lingkungan. Prosiding Ekspose Penerapan Hasil Litbang Hutan dan Konservasi Alam. Pusat Litbang Hutan dan Konservasi Alam. Puslitbang Hutan dan Konservasi Alam Bogor.

[8] Effendi, R. 2011. Pertumbuhan Produksi Nyawai (Ficus variegata Bl) di KHDTK Cikampek. Laporan intern. Puslitbang Peningkatan Produktivitas Hutan Bogor.

[9] Asefa G. 2019. The role of harvest index in improving crop productivity. Journal of Natural Science Research 9(6): 24-28. DOI: 10.7176/JNSR/9-6-04.

[10] Rahmawathi AM, Wijayanto N, Wulandari AS. 2017. Growth analysis of sentang (Azadirachta excelsa) in agroforestry system. Biodiversitas 18(2): 589-592. DOI: 10.13057/biodiv/d180220.

[11] Kenya Agricultural Research Institute (KARI). 2009. Kenya Agricultural Research Institute Annual Report

[12] Gladwin C.H., Peterson J.S., Phiri D., Uttaro R. (2002). Agroforestry adoption decisions, structural adjustment and gender in Africa. In C. B. Barrett, F. Place \& A. A. Aboud 
(Eds.), Natural Resources Management in African Agriculture: Understanding and improving current practices (pp. 115-128).

[13] Connolly-Boutin L., Smit B. (2016). Climate change, food security, and livelihoods in sub-Saharan Africa. Regional Environmental Change, 16(2), 385-399.

[14] Meijer, S.S., Catacutan D., Ajayi O.C., Sileshi G.W., Nieuwenhuis M. (2015). The role of knowledge, attitudes and perceptions in the uptake of agricultural and agroforestry innovations among smallholder farmers in sub-Saharan Africa, International Journal of Agricultural Sustainability, 13:1, 40-54, DOI: 10.1080/14735903.2014.912493. 